\title{
COMPARISON OF AEROBIC POWER AND CAPACITY BETWEEN ATHLETES FROM DIFFERENT SPORTS
}

\author{
COMPARAÇAO DA POTÊNCIA ECAPACIDADE AERÓBICA ENTREATLETAS DE ALTO RENDIMENTO DE \\ DIFERENTES MODALIDADES ESPORTIVAS
}

\begin{abstract}
COMPARACIÓN DE POTENCIA Y CAPACIDAD AERÓBICA ENTRE ATLETAS DE ALTO RENDIMIENTO DE DIFERENTES MODALIDADES DEPORTIVAS
\end{abstract}

\begin{abstract}
Fabiano de Barros Souza (Physical Education Professional) $^{1}$ Ricardo Cesar Alves Ferreira (Physical Education Professional) $^{2}$ Wendel Simoes Fernandes (Pharmacist) $)^{2}$ Wellington Ribeiro (Pharmacist) ${ }^{1}$ Rodrigo Alexis Lazo-Osorio (Physiotherapist) $^{1}$

1. Instituto de Pesquisa e Desenvolvimento (IP\&D), Universidade do Vale do Paraíba (Univap), São José dos Campos, SP, Brazil.

2. Instituto de Ciencias da Saude (ICS), Universidade Paulista (UniP), São José dos Campos, SP, Brazil.
\end{abstract}

\section{Correspondence:}

Ricardo Cesar Alves Ferreira Instituto de Pesquisa e Desenvolvimento (IP\&D), Universidade do Vale do Paraíba (Univap), Avenida Shishima Hifumi, 2911, CEP: 12244-000, Urbanova, São José dos Campos, SP, Brazil. ricardocalves@hotmail.com

\begin{abstract}
Introduction: Ergospirometry is a noninvasive procedure used to assess physical performance or the capacity of an individual, through an analysis of expired gases and respiratory variables. This procedure is crucially important in sports, and makes a significant contribution to the measurement of cardiorespiratory fitness indices, such as maximal oxygen consumption ( $\mathrm{VO}_{2} \mathrm{max}$ ) and the anaerobic threshold (AT). Objective: To assess aerobic capacity and potency in professional and junior soccer players, handball athletes, and women soccer players. Methods: Forty-eight athletes participated voluntarily and were divided into 4 groups. The first group consisted of 12 youth soccer players in the under-20 category, the second group was made up of 12 professional soccer players, the third group was made up of female soccer players, and the fourth group consisted of handball players. Results: We analyzed values such as peak $\mathrm{VO}$, average speed and heart rate at the anaerobic threshold as well as pulmonary ventilation. We found that the values were always greater for the group formed by professional soccer players, with the exception of mean maximum $\mathrm{O}_{2}$ consumption, in which the difference between this group and that of soccer players in the junior category was not significant. In other physical valences, there was a degree of similarity between the other groups, with special emphasis on pulmonary ventilation, which was significantly lower in the group of female soccer players. Conclusion: The particularities of each sport, such as pitch dimensions, duration, and tactical system, together with the morphology and sex of the athletes, directly influence peak $\mathrm{VO}_{2}$, AT and VE values in athletes who play different sports. Level of Evidence III; Development of diagnostic criteria in consecutive patients (with gold reference standard applied).
\end{abstract}

Keywords: Spirometry; Sports medicine; Soccer; Physiology; Ventilation.

\section{RESUMO}

Introdução: A ergoespirometria é um procedimento não invasivo, utilizado para avaliar o desempenho físico ou a capacidade de um indivíduo, pela análise de gases espirados e variáveis respiratórias. No esporte, é de fundamental importância e traz significativa contribuição na verificação de índices de aptidão cardiorrespiratória, como é o caso do consumo máximo de oxigênio ( $\mathrm{VO}_{2}$ máx.) e do limiar anaeróbico (LA). Objetivo: Avaliar a potência e a capadidade aeróbica em atletas profissionais ejuniores do futebol, atletas de handebol e mulheres futebolistas. Métodos: Participaram voluntariamente 48 atletas divididos em 4 grupos. O primeiro grupo foi composto por 12 jovens futebolebolistas na categoria sub-20, o segundo grupo era formado por 12 futebolistas profissionais, o terceiro grupo foi formado por futebolistas do sexo feminino e o quarto grupo, por atletas de handebol. Resultados: Foram analisados valores como pico de $\mathrm{VO}_{2}$, velocidade média e frequência cardíaca do limiar anaeróbico, além da ventilação pulmonar; verificaram- se valores sempre maiores para o grupo formado por jogadores de futebol profissional com exceção do valor médio de consumo máximo de $\mathrm{O}_{2}$ no qual a diferença para futebolistas da categoria juniores não foi significativa. Em outras valências fisicas, houve alguma semelhança entre os demais grupos, com destaque para a ventilação pulmorar, que foi significativamente menor no grupo de futebol feminino. Conclusão: As especificidades da modalidade, como dimensões do campo de jogo, tempo de duração, sistema tático, em conjunto com a morfologia e o sexo dos atletas influenciam diretamente os valores de VO ${ }_{2}$ pico, LA eVE nos atletas de diferentes modalidades. Nível de Evidência III; Desenvolvimento de critérios diagnósticos em pacientes consecutivos (com padrão de referência "ouro" aplicado).

Descritores: Espirometria; Medicina esportiva; Futebol; Fisiologia; Ventilaçao.

\section{RESUMEN}

Introducción: La ergoespirometría es un procedimiento no invasivo, utilizado para evaluar el desempeño físico o la capacidad de un individuo, utilizando análisis de gases espirados y variables respiratorias. En el deporte, es de fundamental importancia y trae significativa contribución en la verificación de índices de aptitud cardiorrespiratoria, como es el caso del consumo máximo de oxígeno (VO2 máx.) y el umbral anaeróbico (UA). Objetivo: Evaluar la potencia y la capacidad aeróbica en atletas profesionales y juveniles de fútbol, atletas de hándball y mujeres futbolistas. Métodos: Participaron voluntariamente 48 atletas divididos en 4 grupos. El primer grupo fue compuesto por 12 jóvenes futbolistas en la categoría sub-20, el segundo grupo era formado por 12 futbolistas profesionales, el tercer grupo fue formado 
por futbolistas del sexo femenino, y el cuarto grupo por atletas de hándball. Resultados: Se analizaron valores como pico de VO2, velocidad promedio y frecuencia cardíaca del umbral anaeróbico, además de la ventilación pulmonar; se verificaron valores siempre mayores para el grupo formado por jugadores de fútbol profesional con excepción del valor promedio de consumo maximo de $\mathrm{O}_{2}$ donde la diferencia para futbolistas de la categoría junior no fue significativa. En otras valencias fisicas hubo cierta semejanza entre los demás grupos, pudiendo ser destacada la ventilación pulmonar, que fue significativamente menor para el grupo de fútbol femenino. Conclusión: Las especificidades de la modalidad, como dimensiones del campo de juego, tiempo de duración, sistema táctico, en conjunto con la morfología y sexo de los atletas influyen directamente en los valores de VO ${ }_{2}$ pico, UA y VE en los atletas de diferentes modalidades. Nivel de Evidencia Ill; Desarrollo de criterios diagnósticos en pacientes consecutivos (con patrón de referencia "oro" aplicado).

Descriptores: Espirometría; Medicina deportiva; Fútbol; Fisiología; Ventilación.

\section{INTRODUCTION}

Oxygen uptake $\left(\mathrm{VO}_{2}\right.$ max.) can be defined as a maximal volume of oxygen that a individual person can absorb per time unit. ${ }^{1,2,3} \mathrm{VO}_{2}$ Peak is the higher value observed during the effort test, it has been considered a important performance parameter, because the capacity of human to be able for long term exercise e depends priority of aerobic metabolism. Overall, a index useful to determine a capacity functional cardiorespiratory in athletes. 2,3,4 The Oxygen Uptake was for long time the more important and used pathway to show aerobic skills, but some research's has been showing that index isn't enough to discriminate performance in aerobic events. ${ }^{5}$ And it has permanent of these methods of training and means the rates for athletic fitness aerobic for sport becomes pertinent. ${ }^{6}$ The anaerobic threshold is the point where the transition from aerobic to anaerobic metabolism occurs and is also an index that satisfactorily reflects physical fitness, being used in training as an evaluation and in the training of athletes. ${ }^{1,5}$ When the edge is removed from the respiratory rays, it can be defined as a stress current on the production of lactic acid that exceeds its removal, having a hyperventilation as a consequence. ${ }^{7}$

Ergospirometry, a non-invasive and useful procedure for the evaluation of physical exercise or functional capacity of an individual, reconciles an analysis of gas, sneezing, respiratory variables and oximetry., ${ }^{89}$ This method is able to determine the performance indicators, such as the exercise intolerance option and a metabolic mean of performance in exercise prescription. ${ }^{1,3}$

Football presents changes of intensity, small recovery pauses, acceleration and deacceleration, abrupt stops and changes of direction, that is, athletes experience the intermittent movements of nature during training and competitions. Other characteristics, energy production by children is more important, mainly, aerobic metabolism, which is related to the ability to maintain the intensity of effort during play by the recovery of high intensity stimuli. ${ }^{5}$

Handball requires a high level of general and specific conditioning, the effective time of a match is 40 minutes, with consecutive and challenging attacks in high intensity and different components such as accelerations, changes of direction and jumps, a diversity of arguments requires thorough preparation in terms of strength, speed and speed. ${ }^{10}$

\section{METHOD}

Was tested 48 athletes they were divided into 4 groups of 12 athletes. The group 1 was builded of 12 young men playing soccer in the Under 20 division, with mean age of $17( \pm 0.5)$ years and mean weight of 67.8 $( \pm 4.5) \mathrm{Kg}$ The second group consisted of 12 professional soccer players (FMP), with a mean age of 23 ( \pm 1.6 ) years and mean weight of 73.1 $( \pm 4.7) \mathrm{kg}$, the third group was formed by footballers (FF), with a mean age of $21( \pm 1.3)$ and mean weight of $57.6( \pm 3.1) \mathrm{kg}$, and finally the fourth group was formed by handball athletes $(\mathrm{MH})$ with age mean of $19( \pm 1.3)$ and mean weight of $83.8( \pm 7) \mathrm{kg}$.
The study was submitted and approved by the Ethics and Research Committee (CEP) of the University of Vale do Paraíba-UNIVAP. Individuals were informed of this study and a consent form was applied, as determined by resolution 196/96 of the CNS.

A Micromed digital electrocardiograph was used for the study to record and analyze the ECG during exercise; an Inbrasport treadmill, Super ATL model; a VO 2000 gas analyzer of the MedGraphics brand, coupled to a microcomputer, equipped with the Elite software produced by Micromed; nasal clip; disposable electrodes; disposable razor blades; disposable cartridges; alcohol 70.

The tests were performed in the pre-season, more precisely in the pre-competitive period of the four groups of athletes studied in the Laboratory of Evaluation of Physical Effort-LAEF, at the Faculty of Health Sciences-FCS of the University of Vale do Paraíba-UNIVAP. The tests were performed in a controlled environment, at an ambient temperature of $24^{\circ} \mathrm{C}$, and with a relative humidity of $60 \%$. The evaluation protocol used was progressive, with steady slope of $2 \%$ and initial velocity of $4.0 \mathrm{~km} /$ $\mathrm{h}$. There was an increase of speed of $1.0 \mathrm{~km} / \mathrm{h}$ every minute of test until the fourth minute; after the fourth minute the speed increase was also $1.0 \mathrm{~km} / \mathrm{h}$, but occurring every two minutes of testing. The duration of the tests was determined by the exhaustion of the athlete, who when it reached it signaled to the evaluator, who then started the recovery phase with an initial velocity of $5.0 \mathrm{~km} / \mathrm{h}$, decreasing by $1.0 \mathrm{~km} / \mathrm{h}$ after the first minute held until the end of recovery, determined by the stabilization of the athlete's heart rate.

For the statistical analysis of the data, the One Way-ANOVA variance test was used, considering a level of significance of $5 \%(p<0.05)$.

\section{RESULTS}

FMP versus FF $p=0.000$ (\#); FMP versus $\mathrm{HM} p=2.92 \mathrm{E}^{-4}(\psi)$; FMJ versus FF $p=0.000(\theta)$; FMJ versus $H M p=0.009(\delta) ; H M$ versus FF $p=0.001(\Phi)$.

FMP versus FMJ $p=0.013\left(^{*}\right)$; FMP versus FF $p=7.71 E^{-6}(\#)$; FMP versus $\mathrm{HM} \mathrm{p}=5.88 \mathrm{E}^{-5}(\psi)$.

FMP versus FMJ $p=0.026(*) ; F M P$ versus FF $p=5.15 E^{-5}(\#) ; F M P$ versus $\mathrm{HM} \mathrm{p}=0.002(\psi)$.

FMP versus FMJ $p=0.001\left(^{*}\right)$; FMP versus FF $p=4.38 E^{-8}(\#)$; FMP versus $\mathrm{HM} p=0.007(\psi)$; FMJ versus FF $p=0.025(\theta) ; \mathrm{HM}$ versus FF $p=0.006(\Phi)$.

Table 1. Mean and SD of the anthropometric values (weight and age) and analyzed parameters $\left(\mathrm{VO}_{2}\right.$ and $\left.\mathrm{VE}\right)$.

\begin{tabular}{c|c|c|c|c|c|c}
\hline Group & Age (year) & $\begin{array}{c}\text { Weight } \\
\mathbf{( K g )}\end{array}$ & VE (I/min) & $\begin{array}{c}\text { VO2 Peak } \\
(\mathbf{m l} / \mathbf{k g} \cdot \mathbf{m i n})\end{array}$ & $\begin{array}{c}\text { Anaerobic } \\
\text { Threshold } \\
\mathbf{( K m / h})\end{array}$ & $\begin{array}{c}\text { HR } \\
\text { Threshold } \\
\mathbf{( b p m})\end{array}$ \\
\hline FMJ & $17.17 \pm 0.58$ & $67.82 \pm 4.54$ & $96.83 \pm 6.86$ & $56.48 \pm 3.08$ & $13.64 \pm 0.45$ & $159.17 \pm 3.66$ \\
\hline FMP & $23.25 \pm 1.66$ & $73.15 \pm 4.72$ & $111.59 \pm 12.64$ & $58.15 \pm 4.48$ & $14.24 \pm 0.37$ & $163.42 \pm 4.21$ \\
\hline FF & $21.17 \pm 1.34$ & $57.67 \pm 3.14$ & $85.89 \pm 4.21$ & $46.04 \pm 2.90$ & $13.18 \pm 0.59$ & $156.17 \pm 2.76$ \\
\hline HM & $19.00 \pm 1.28$ & $83.83 \pm 7.02$ & $98.79 \pm 10.24$ & $51.70 \pm 3.42$ & $13.30 \pm 0.44$ & $157.91 \pm 3.51$ \\
\hline
\end{tabular}




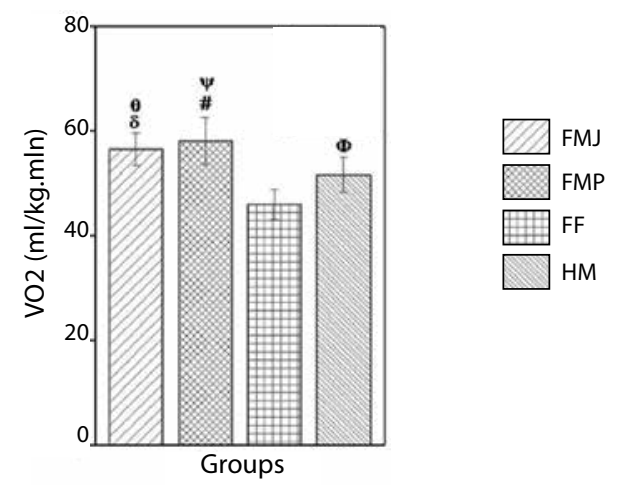

Figure 1. $\mathrm{VO}_{2}$ peak athlets em diferent sports.

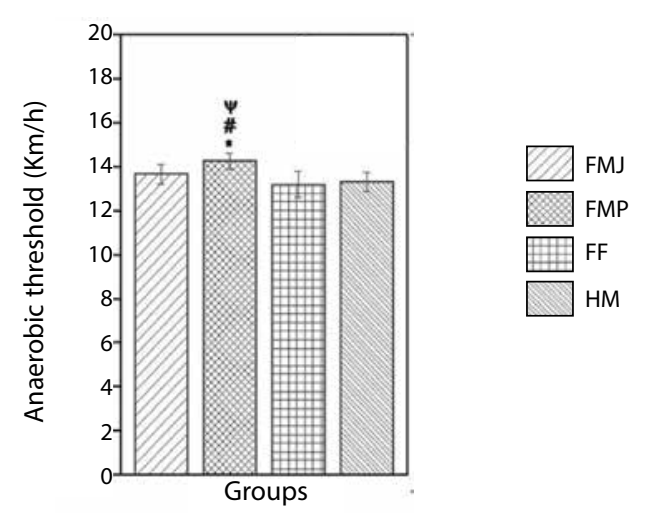

Figure 2. Threshold speed athlets em diferent sports.

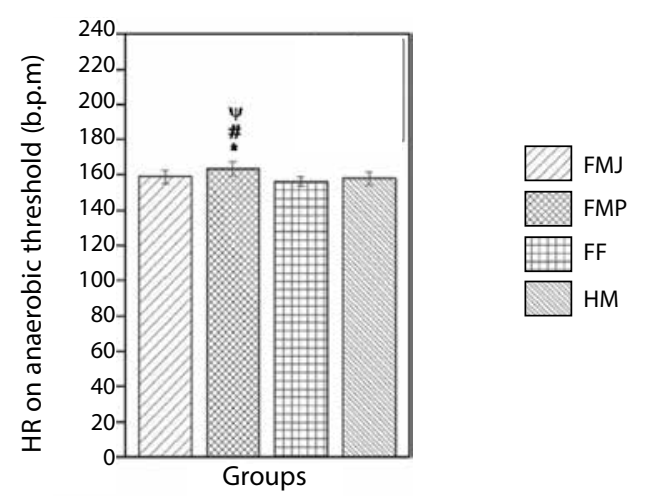

Figure 3. HR on lactate threshold athlets em diferent sports.

\section{DISCUSSION}

In this research we can see some important differences, featuring FMP group presenting significant results in VO2 peaks when compared to results of the same physiological parameters obtained in the FF and $\mathrm{H}$ groups. When compared to the VO2 of the FMP with the VO2 of the FMJ, there was no significant difference in their results. This fact was

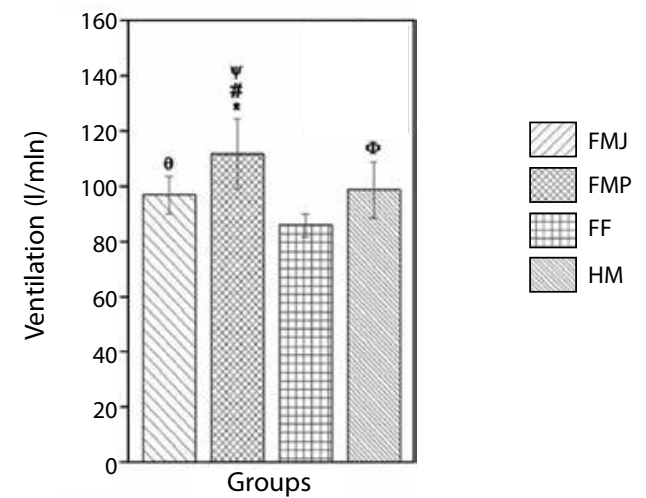

Figure 4. Ventilation athlets em diferent sports.

discussed in several studies, such as ${ }^{2,3}$ which studied the performance of soccer players and showed similarity in the morphological physical composition of the players, with muscle mass being the main factor of balance between the two categories, as analyzed in the present study. The methodology used in physical and technical training in the soccer modality is similar in both categories with regard to the intensity and volume of training?

Still in relation to VO2peak, the FF and $\mathrm{H}$ groups obtained significantly lower values in relation to the field soccer groups (FMP and FMJ). The result should be according to $7,8,9$ a factors such as the difference in lean mass (lower weight in muscle in female athletes). In relation to Handball, researchers such as, ${ }^{8}$ distinguish in their work the occurrence of adaptations of different physical valences caused by the specificity of the spaces where the training and games are developed. Modalities practiced in larger environments allow better aerobic power conditions. ${ }^{2,3,7,8}$

As in aerobic power, the velocity $(\mathrm{km} / \mathrm{h})$ and heart rate $(\mathrm{bpm})$ values of the anaerobic threshold of the FMP group were significantly higher than the other groups, except for the FF threshold HR. E. There was no significant difference between the other groups when compared.

These results can be related not only to the environment where the sport is practiced, but also as a consequence of a good aerobic power, which directly influences the values obtained in aerobic capacity., ${ }^{3,11}$

Another consideration to be made is muscle efficiency, since professional soccer athletes have a training methodology that is very similar to $\mathrm{u}-20 \mathrm{foo}-$ tballers. However, due to the results obtained, it is possible to consider more efficiency of the musculature required of professional soccer athletes. 9,12,13

Regarding pulmonary ventilation, the FMP group also presents a higher average value when compared to the others. The female group has a lower average value in relation to the other groups, which is related to the morphological difference of the woman, especially in relation to the respiratory system and its capabilities.

\section{CONCLUSION}

The Results showed that the enviroment specificity where the sport is, and the caracteristics of practices and training, interferes in uptake e oxygen in elite athlets.

All authors declare no potential conflict of interest related to this article.

AUTHORS' CONTRIBUTIONS: Each author made significant individual contributions to this manuscript. RCAF (0000-0003-1585-5311)* was responsible for the preparation and writing of the text, FBS $(0000-0002-5133-652 X)^{*}$ was the instructor responsible for the data collection, conducting the assessments with the athletes; WR (0000-0003-1708-0476)* and RALO (0000-0002-2741-0638)* made a crucial contribution to the interpretation and discusson of the data used in the drafting of the manuscript. WSF (0000-0002-4749-3821)* was responsible for the statistical analyses and composition of graphs. RCAF and WR carried out the literature search and the review of the manuscript. All authors contributed to the intellectual concept of the study. ${ }^{*} \mathrm{ORCID}$ (Open Researcher and Contributor ID). 


\section{REFRENCES}

1. Leal Jr ECP, Souza FB, Magini M, Martins RABL. Estudo comparativo do consumo de oxigênio e limiar anaeróbio em um teste de esforço progressivo entre atletas profissionais de futebol e futsal. Rev Bras Med Esporte. 2006 Nov/Dez; 12(6): 323-326

2. Grieco CR, Cortes N, Greska EK, Lucci S, Onate JA. Effects of a Combined Resistance/Plyometric Training Program on Muscular Strength, Running Economy and VO2peak in Division I Female Soccer Players. Strength Cond Res. 2012 Sep;26(9):2570-6.

3. Dittrich N, da Silva JF, Castagna C, de Lucas RD, Guglielmo LG. Validity of Carminatti's test to determine physiological indices of aerobic power and capacity in soccer and futsal players. J Strength Cond Res. 2011 Nov;25(11):3099-106.

4. Bassett DR Jr, Howley ET. Limiting factors for maximum oxygen uptake and determinants of endurance performance. Med Sci Sports Exerc. 2000 Jan;32(1):70-84

5. da Silva JF, Dittrich N, Guglielmo LGA. Avaliação aeróbia no futebol. Rev Bras Cineantropom Desempenho Hum. 2011; 13(5):384-391.

6. Nicolao ALA, Pedrinelli A, Zogaib PSM, Orbetelli R, Neto TLB. Influência da Maturação Sexual no Limiar de Lactato em Jogadoras de Futebol. Rev Bras Med Esporte. 2010 Set/Out; 16(5): 335-338.
7. Cunha G, Lorenzi T, Sapata K, Lopes AL, Gaya AC, Oliveira Á. Effect of biological maturation on maximal oxygen uptake and ventilatory thresholds insoccer players: an allometric approach. J Sports Sci. 2011 Jul;29(10):1029-39.

8. Van Den Tillaar R, Cabri JM.Gender differences in the kinematics and ball velocity of overarm throwing in elite team handball players. J Sports Sci. 2012;30(8):807-13.

9. da Silva JF, Castagna C, Carminatti LJ, Foza V, Guglielmo LG, de Oliveira FR. Physiological demands of team-handball referees during games. J Strength Cond Res. $2010 \mathrm{Jul} ; 24(7): 1960-2$.

10. Boraczyński T, Urniaż J. Changes in aerobic and anaerobic power indices in elite handball players following a 4-week general fitness mesocycle. Journal of human kinetics. 2008(19): 131-140.

11. Buchheit M, Lepretre PM, Behaegel AL, Millet GP, Cuvelier G, Ahmaidi S. Cardiorespiratory responses during running and sport-specific exercises in handball players. J Sci Med Sport. 2009 May;12(3):399-405

12. Bradley PS, Sheldon W, Wooster B, Olsen P, Boanas P, Krustrup P. High-intensity running in English FA Premier League soccer matches. J Sports Sci. 2009 Jan 15;27(2):159-68.

13. Da Silva CD, Bloomfield J, Marins JC. A review of stature, body mass and maximal oxygen uptake profiles of U17, U20 and first division players in Brazilian soccer, J Sports Sci Med. 2008 Sep 1;7(3):309-19. 